\title{
Mathematical Modeling of Drying Characteristics of Black Pepper (Piper nigrum) in Indirect Type Solar-Biomass Hybrid Dryer
}

\author{
R. Shreelavaniya ${ }^{1 *}$, R. Pangayarselvi ${ }^{2}$ and S. Kamaraj ${ }^{1}$ \\ ${ }^{1}$ Department of Bioenergy, ${ }^{2}$ Department of Physical Science and Information Technology, \\ Agricultural Engineering College and Research Institute, Tamil Nadu Agricultural University, \\ Coimbatore- 641003, Tamil Nadu, India \\ *Corresponding author
}

\section{A B S T R A C T}

\begin{tabular}{|l|}
\hline Ke y w o r d s \\
$\begin{array}{l}\text { Drying model, Black } \\
\text { pepper drying, Solar- } \\
\text { Biomass hybrid } \\
\text { drying, Open sun } \\
\text { drying. }\end{array}$ \\
\hline Article Info \\
\hline $\begin{array}{l}\text { Accepted: } \\
\text { 20 September } 2017 \\
\text { Available Online: } \\
\text { 10 November } 2017\end{array}$ \\
\hline
\end{tabular}

Keywords

Drying model, Black Biomass hybrid drying, Open sun rying.

\section{Introduction}

Among the spices, Black pepper (Piper nigrum L.) known as the "King of spices", is a perennial climbing vine of the tropics, belonging to the family Piperaceae, which is indigenous to the tropical forests of Western Ghats of South India. It is one of the important and earliest known spices produced and exported from India. It is economically the most important and the most widely used spice crop of the world. Pepper is valued for its pungency contributed by the alkaloid piperine and flavor contributed by the volatile oil. It has extensive culinary uses for flavouring and preserving processed food and is important medicinally. Drying is defined as a process of moisture removal due to simultaneous heat and mass transfer. It is a classical method of food preservation, which provides longer shelf-life, lighter weight for transportation and small space for storage. The drying process takes place in two stages. The first stage happens at the surface of the drying material at constant drying rate and is similar to the vaporization of water into the ambient. The second stage takes place with decreasing (falling) drying rate. The condition of the second stage is determined by the properties of the material being dried. Drying is the most important part of the process as it affects the quality of the final product which 
will decide profitability. Open sun drying (OSD) is the most commonly used method to preserve agricultural products like grains, fruits and vegetables in most developing countries. Such drying under hostile climate conditions leads to severe losses in the quantity and quality of the dried product. These losses related to contamination by dirt, dust and infestation by mould, insects, rodents and animals. Therefore, the introduction of solar-biomass hybrid dryers can reduce crop losses and improve the quality of the dried product significantly when compared to the traditional methods of drying such as sun or shade drying. The present practice for drying fresh pepper berries is open sun drying immediately after harvesting as it is perishable due to its high moisture content. Therefore, drying removes the moisture content and preserves pepper for longer periods of time. There are many problems associated with sun drying method, such as lack of sufficient control during drying, being extremely weather dependent, contamination with dust, soil and insects and undesirable changes in the quality of products.

The indirect solar-biomass hybrid system (SBHD) was designed and it was fabricated at Bioenergy workshop, Department of Bioenergy, Agricultural Engineering College and Research Institute, Tamil Nadu Agricultural University (TNAU), Coimbatore, Tamil Nadu. The experimental unit was installed and the performance was evaluated at Horticultural Research Station, Tamil Nadu Agricultural University, Thadiyankudisai, Dindigul district, Tamil Nadu. Mathematical modeling has been widely used for the analysis of drying processes of agricultural products. There is limited information available on the drying kinetics of spices. However, no studies have been found on the drying kinetics of black pepper (Piper nigrum) in a solar-biomass hybrid dryer. It is therefore the objective of this work was to evaluate the mathematical model for the drying of black pepper and to study the quality characteristics of the dried black pepper product.

\section{Materials and Methods}

Freshly harvested black pepper, Piper nigrum (Panniyur-I variety) procured from Horticultural Research Station (HRS), Thadiyankudisai, Dindigul district, Tamil Nadu was used for this experiment. Immediately after harvesting the spike from vines, they were trampled to separate the pepper berries from spikes.

\section{Solar-Biomass Hybrid Dryer (S-BHD)}

A solar-biomass hybrid dryer with data acquisition system was used in these experimental trials. The cover material or glazing sized $2 \mathrm{~m} \mathrm{x} 1 \mathrm{~m}$ and $4 \mathrm{~mm}$ thickness polycarbonate sheet was placed at the top of the collector. The absorber plate sized $2 \mathrm{~m} \times 1$ $\mathrm{m}$ and $0.001 \mathrm{~m}$ thickness is made of perforated v- ribbed, special surface coated with black paint aluminum sheet. The absorber was implicit to be a perfect black body and absorbed maximum heat. The Aluminum steel was used for fabrication of the absorber because it has a high value of adsorption (0.93) and low value of emissivity (0.1). The solar flat plate collector was insulated with polyurethane foam (PUF) of thickness $30 \mathrm{~mm}$ and externally finished with galvalum sheet to protect it from rain water and all climatic conditions. Polyurethane foam is used to minimize the heat loss from the solar collector. Polyurethane (PU) flexible hose was used for conveying hot air produced from flat plate solar collector to drying chamber. The drying chamber dimension $(1 \mathrm{~m}$ $\times 1 \mathrm{~m} \times 1 \mathrm{~m})$ was insulated with polyurethane foam (PUF) of thickness $50 \mathrm{~mm}$ and finished with aluminum sheet to withstand all climatic conditions. Polyurethane foam is used to 
minimize the heat loss from the drying chamber. The chamber was fully air tight to minimize heat loss from its walls. Inside the chamber, trays are placed which are made up of perforated aluminium sheet of $1 \mathrm{~mm}$ hole size which slides over aluminium L - angle. The drying chamber was supported with the help of a frame made up of stainless steel (SS) angle. The frame was attached to a stand made up of stainless steel angle of height 0.5 $\mathrm{m}$.

The biomass air heating system consists of two chambers. The first chamber is the combustion chamber for burning biomass or agro residues. The second chamber is the gas to air heat exchanger consisting of outer shell and inner tubes for exchanging heat between hot flue and fresh air. The flue gas moves through the heat exchanger pipe by natural draft assisted by a chimney and the fresh air flows across the pipes of the heat exchanger in cross flow pattern. During its flow in the heat exchanger, the heat from hot flue gas is transferred to the fresh air. The hot air obtained from biomass air heating system is forced to drying chamber to facilitate continuous drying of black pepper during night time or cloudy season.

\section{Experimental design}

Drying trials were carried out in solarbiomass hybrid dryer with an open sun drying control treatment for evaluating the effect on quality characteristics of black pepper.

\section{Solar-Biomass hybrid drying experiments}

The solar-biomass drying experiments were carried out during March-May 2016 at the Horticultural Research Station of TNAU. The freshly harvested pepper of $20 \mathrm{~kg}$ was placed in the solar-biomass hybrid dryer at 8 a.m and simultaneously the other was placed under sun for a particular trial. Both trials were dried until a final moisture content of 8 to $10 \%$ (d.b) was obtained. The first trial was dried using the rise of fresh air temperature by solar collector until evening (5 p.m.), and during the night time, the drying was continued by biomass air heating system to raise the internal temperature until the next morning. Black pepper placed under open sun drying (OSD) was stored in sealed plastic bags during the night time and placed under sun the next day.

\section{Dryer operating procedure}

The temperature was measured using RTD type temperature sensors. The RTD sensors used in this study are three wire RTD platinum sensors which are encapsulated in SS304 body with open wire at its ends to measure the temperature. The relative humidity inside drying chamber was measured using temperature and relative humidity transmitter. The instrument has relative humidity measuring range of 0 to 100 per cent with \pm 2 per cent accuracy using thin film polymer capacitor. The weather parameters such as ambient temperature and ambient RH, wind velocity, wind direction, solar radiation and rainfall details were measured using an automatic weather station. The weather station (model: Vantage Pro, Make: Davis) includes two components: the Integrated Sensor Suite (ISS) and the console. The ISS contains the sensor interface module (SIM), rain collector, an anemometer, and a passive radiation shield. All the sensors are connected to PC with 8-channel scanner data acquisition system installed with eScan 9.0 version software and powered by switchedmode power supply (SMPS) unit for continuous monitoring of solar-biomass hybrid drying system. The continuous monitoring helps in regulating the constant environment throughout the drying period, thus avoids the deterioration of quality of the product. 


\section{Biochemical and microbiological analysis}

The volatile oil and oleoresin content were analyzed using ASTA, 1997 method. The piperine content was estimated by Spectrophotometric Method. The enumeration of yeast and mold were tested by FDA Bacteriological Analytical Manual (BAM) 2001 method.

\section{Statistical analysis}

The coefficient of determination $\left(\mathrm{R}^{2}\right)$, reduced chi-square $\left(\chi^{2}\right)$, and the percentage of root mean square error (RMSE) were used for selecting the best-fit equation to describe the drying process. All data are expressed as mean and S.D. In this study, statistical analyses were performed by non-linear regression using statistical software, SPSS 16.0 version.

\section{Drying efficiency}

Drying efficiency indicates the overall thermal performance of the drying system, including collector efficiency and dryer efficiency. System efficiency for forced convection solar dryers needs to take into account the energy consumed by the fan/blower and it is calculated by using the following relation

$\eta_{s}=\frac{W \times L}{(I \times A)+P_{f}}$

For biomass air heater, the system efficiency is given by

$\eta_{s}=\frac{W \times L}{m_{b} \times C V}$

For hybrid dryers, which use additional energy from a second source (e.g. biomass, LPG etc.), the system efficiency is given by

$$
\eta_{s}=\frac{W \times L}{\left(I A+P_{f}\right)+\left(m_{b} \times C V\right)}
$$

The drying efficiency of Solar-Biomass Hybrid Dryer indicates how effectively the input energy to the dryer (biomass energy and solar radiation) is used in drying the product. The calorific value of coconut shell was estimated as $22.43 \mathrm{MJ} / \mathrm{kg}$.

\section{Drying model confirmation for black pepper drying in solar-biomass hybrid dryer}

The published literature revealed that there is no single drying model that is suitable for describing the drying kinetics of all products. However, the mathematical model listed in Table 1 was fitted more appropriately to describe the thin-layer drying of many fruits and agricultural products. Therefore, mathematical models were used for predicting the drying curves (Cassini et al., 2007) of black pepper in S-BHD and OSD methods. The drying curves obtained from different drying methods were fitted with moisture ratio equations. However, the moisture ratio (MR) was simplified to $\mathrm{M} / \mathrm{M}_{0}$ instead of (M$\left.M_{e}\right) /\left(M_{0}-M_{e}\right)$ because relative humidity of the drying air continuously fluctuated in the drying chamber as explained by Togrul and Dursun (2002).

The best drying model was selected based on the maximum coefficient of determination $\left(\mathrm{R}^{2}\right)$ of drying curves of the dried samples, the minimum values of reduced chi-square $(\chi 2)$ as the mean square of the deviations between the experimental and calculated values, and the percentage of root mean square error (RMSE) as reported by Yaldiz et al., (2001)These parameters can be calculated from:

$\chi^{2}=\frac{\sum_{i=1}^{N}(M R \exp , i-M R \text { pre }, i)^{2}}{N-n}$ 
$R M S E=\left[\frac{1}{N} \sum_{i=1}^{N}\left(M R \text { pre }_{,} i-M R \exp , i\right)^{2}\right]^{1 / 2}$

\section{Results and Discussion}

\section{Drying characteristics of black pepper} under solar-biomass hybrid drying

The important parameters like temperature, relative humidity, solar radiation under ambient condition and temperature obtained at various points of solar-biomass hybrid dryer were recorded.

The ambient temperature varied from $17.0^{\circ} \mathrm{C}$ to a maximum of $30.1^{\circ} \mathrm{C}$. The ambient relative humidity varied from 50 per cent to 100 percent. The solar intensity varied from $40.7 \mathrm{~W} \mathrm{~m}^{-2}$ to $865.2 \mathrm{~W} \mathrm{~m}^{-2}$ during the typical drying experiments.

The initial moisture content of black pepper was 434.8 per cent d.b and was reduced to 9.4 per cent d.b for a drying period of $12 \mathrm{~h}$. The maximum drying rate of $16.5 \mathrm{~g} / \mathrm{h}$ was obtained during initial stage of drying and it reached $4.4 \mathrm{~g}$ at the end of drying period of 12 hours.

The moisture ratio against drying time for drying of black pepper, which shows that the moisture ratio of black pepper reduced gradually over a period of time. The drying characteristics of Black pepper in SolarBiomass hybrid dryer is shown in Figure 1.

The drying of black pepper in S-BHD was much faster than that of the drying of OSD. It took only $12 \mathrm{~h}$ to dry to final moisture content of 9.4 per cent d.b whereas the drying of black pepper at OSD required $84 \mathrm{~h}$ to reach final moisture content of 12.1 per cent d.b.

\section{Drying rate}

Drying of black pepper in S-BHD has a high drying rate initially, but no constant drying rate was found in the whole drying process. The drying rate of black pepper was affected by water content and water contenttemperature interaction.

The drying rate declined as the water content decreased during the drying process. This result is similar to the study on shark fillets drying (Sankat and Mujaffar, 2004).

\section{Drying efficiency}

The average drying efficiency of the solarbiomass hybrid dryer is estimated to be about $33.9 \%$ during black pepper drying.

\section{Solar - Biomass hybrid drying efficiency \\ Energy used to evaporate water $(\mathrm{kJ})=\mathrm{W} \times \mathrm{L}$ $=12.0 \times 2272=27264 \mathrm{~kJ}$}

Energy supplied by coconut shell $(\mathrm{kJ} / \mathrm{Kg})=$ $\mathrm{m}_{\mathrm{b}} \times \mathrm{CV}=40 \times 2243=89720 \mathrm{~kJ}$

Energy input to the dryer $=\mathrm{I} \times \mathrm{A}=450 \times 4$

$$
\begin{aligned}
& =\frac{1800}{27264}=\frac{27264}{(1800+0.56)+(35 \times 2243)} \\
& =\frac{1800.56+78505}{18} \eta_{\mathrm{s}}=33.9 \%
\end{aligned}
$$

\section{Drying efficiency (Biomass only)}

Energy used to evaporate water $(\mathrm{kJ})=\mathrm{W} \times \mathrm{L}$ $=12.0 \times 2272=27264 \mathrm{~kJ}$

Energy supplied by coconut shell $(\mathrm{kJ} / \mathrm{Kg})$

$$
\begin{aligned}
& =\mathrm{m}_{\mathrm{b}} \times \mathrm{CV}=47 \times 2243=105421 \eta_{\mathrm{s}}=\frac{\frac{27264}{105421}}{\eta_{\mathrm{s}}=25.86 \%}
\end{aligned}
$$


Table.1 Mathematical models evaluated for the drying curves

\begin{tabular}{|c|l|l|l|}
\hline No & \multicolumn{1}{|c|}{ Model name } & \multicolumn{1}{|c|}{ Model equation } & \multicolumn{1}{c|}{ References } \\
\hline 1 & Newton & $M R=\exp (-k t)$ & Akpinar et al., $(2003)$ \\
\hline 2 & Page & $M R=\exp \left(-k t^{n}\right)$ & Ilhan et al., $(2007)$ \\
\hline 3 & Henderson and Pabis & $M R=\mathrm{a} \times \exp (-k t)$ & Zhang et al., $(1991)$ \\
\hline 4 & Logarithmic & $M R=\mathrm{a} \times \exp (-k t)+c$ & Jain et al., $(2007)$ \\
\hline 5 & Two-term & $M R=\mathrm{a} \times \exp \left(-k_{0} t\right)+b \times \exp \left(-k_{1} t\right)$ & Henderson et al., $(1974)$ \\
\hline 6 & $\begin{array}{l}\text { Two-term } \\
\text { exponential }\end{array}$ & $M R=\mathrm{a} \times \exp (-k t)+(1-a) \times \exp (-k a t)$ & Sharaf et al., $(1980)$ \\
\hline 7 & Wang and Singh & $M R=1+a t+b t^{2}$ & Waewsak et al., $(2006)$ \\
\hline 8 & Diffusion approach & $M R=a \exp (-k t)+(1-a) \exp (-k b t)$ & Yaldiz et al., $(2001)$ \\
\hline 9 & Verma et al., & $M R=a \exp (-k t)+(1-a) \exp (-g t)$ & Verma et al., $(1985)$ \\
\hline 10 & $\begin{array}{l}\text { Modified Henderson } \\
\text { and Pabis }\end{array}$ & $M R=a \exp (-k t)+b \times \exp (-g t)+c \times \exp (-h t)$ & Karathanos et al., $(1999)$ \\
\hline 11 & Midilli model & $M R=a \times \exp \left(-k t^{n}\right)+b t$ & Midilli et al., (2003) \\
\hline
\end{tabular}

Table.2 Values of the drying constants and coefficients of different models determined through non-linear regression method in S-BHD and OSD

\begin{tabular}{|c|c|c|c|c|}
\hline Model no. & $\mathrm{R}^{2}$ & $\chi^{2}$ & RMSE & Model constant \\
\hline \multicolumn{5}{|c|}{ Solar-Biomass Hybrid Dryer (S-BHD) } \\
\hline 1 & 0.997 & 0.00023 & 0.0001 & $\mathrm{k}=0.1756$ \\
\hline 2 & 0.998 & 0.00020 & 0.0001 & $\mathrm{k}=0.1887 ; \mathrm{n}=0.9599$ \\
\hline 3 & 0.998 & 0.00021 & 0.0001 & $\mathrm{a}=0.9836 ; \mathrm{k}=0.1723$ \\
\hline 4 & 0.998 & 0.00023 & 0.0001 & $\mathrm{a}=0.9900 ; \mathrm{k}=0.1691 ; \mathrm{c}=-0.0082$ \\
\hline 5 & 0.998 & 0.00019 & 0.0000 & $\mathrm{a}=0.0351 ; \mathrm{k}_{1}=14.0916 ; \mathrm{b}=0.9649 ; \mathrm{k}_{2}=0.1686$ \\
\hline 6 & 0.997 & 0.00026 & 0.0001 & $\mathrm{a}=1.0527 ; \mathrm{k}=0.1761$ \\
\hline 7 & 0.988 & 0.00104 & 0.0004 & $a=-0.1470 ; b=-0.0063$ \\
\hline 8 & 0.998 & 0.00017 & 0.0000 & $\mathrm{a}=0.0388 ; \mathrm{k}=1.9953 ; \mathrm{b}=0.0843$ \\
\hline 9 & 0.998 & 0.00035 & 0.0000 & $\mathrm{a}=0.9649 ; \mathrm{k}=0.1686 ; \mathrm{g}=10.8166$ \\
\hline 10 & 0.999 & 0.00035 & 0.0000 & $\begin{array}{l}\mathrm{a}=1.9613 ; \mathrm{k}=0.1865 ; \mathrm{b}=-1.6591 ; \mathrm{g}=-0.1872 ; \mathrm{c}= \\
0.6815 ; \mathrm{h}=0.1679\end{array}$ \\
\hline 11 & 0.999 & 0.00013 & 0.0000 & $\mathrm{a}=0.9984 ; \mathrm{k}=0.1969 ; \mathrm{n}=0.86552 ; \mathrm{b}=-0.00607$ \\
\hline \multicolumn{5}{|c|}{ Open Sun Drying (OSD) } \\
\hline 1 & 0.946 & 0.0168 & 0.0080 & $\mathrm{k}=0.0564$ \\
\hline 2 & 0.732 & 0.0007 & 0.0003 & $\mathrm{k}=0.0026 ; \mathrm{n}=2.1512$ \\
\hline 3 & 0.947 & 0.0094 & 0.0043 & $\mathrm{a}=1.397 ; \mathrm{k}=0.0735$ \\
\hline 4 & 0.999 & 0.0027 & 0.0012 & $\mathrm{a}=5.5146 ; \mathrm{k}=0.0089 ; \mathrm{c}=-4.3869$ \\
\hline 5 & 0.947 & 0.0104 & 0.0012 & $\mathrm{a}=0.6198 ; \mathrm{k}_{1}=0.0735 ; \mathrm{b}=0.6198 ; \mathrm{k}_{2}=0.0735$ \\
\hline 6 & 0.994 & 0.0031 & 0.0014 & $\mathrm{a}=2.2212 ; \mathrm{k}=0.1084$ \\
\hline 7 & 0.998 & 0.0035 & 0.0016 & $\mathrm{a}=-0.0269 ; \mathrm{b}=-0.0006$ \\
\hline 8 & 0.998 & 0.0027 & 0.0011 & $\mathrm{a}=-4.9371 ; \mathrm{k}=0.1731 ; \mathrm{b}=0.7863$ \\
\hline 9 & 0.998 & 0.0027 & 0.0011 & $\mathrm{a}=-6.3565 ; \mathrm{k}=0.1679 ; \mathrm{g}=0.1389$ \\
\hline 10 & 0.998 & 0.0030 & 0.0011 & $\begin{array}{l}a=0.9835 ; k=0.0014 ; b=-3.5540 ; g=-0.0065 ; c= \\
3.6698 ; h=0.0051\end{array}$ \\
\hline 11 & 0.998 & 0.0005 & 0.0002 & $\mathrm{a}=0.9625 ; \mathrm{k}=0.0011 ; \mathrm{n}=2.4735 ; \mathrm{b}=0.00275$ \\
\hline
\end{tabular}


Fig.1 Drying characteristics of Black pepper in Solar-Biomass hybrid dryer

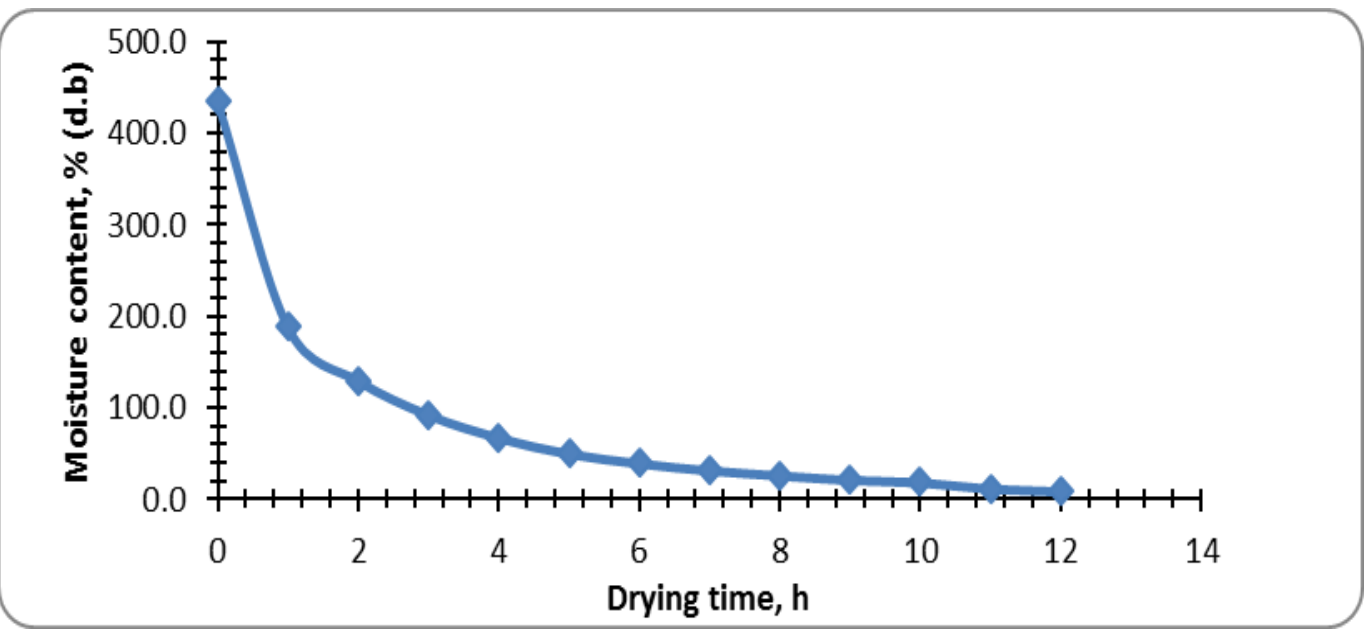

Fig.1a Variations of moisture content with the drying time

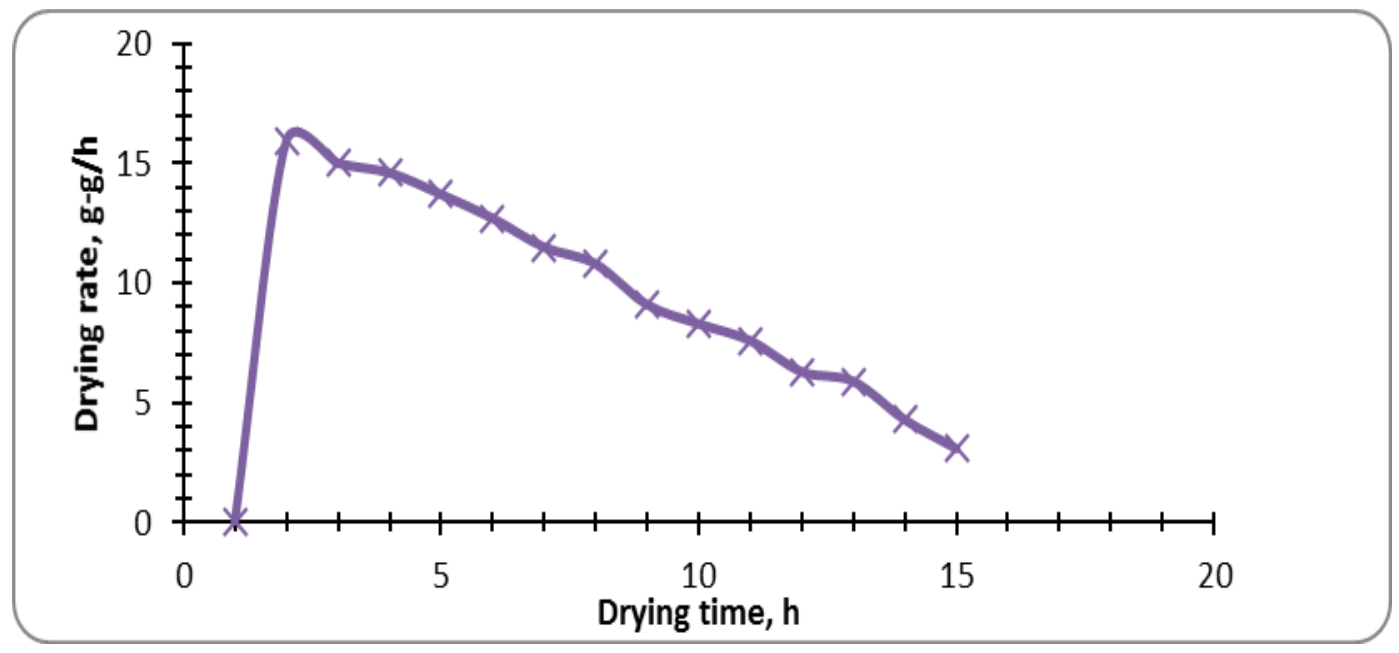

Fig.1b Variations of drying rate with the drying

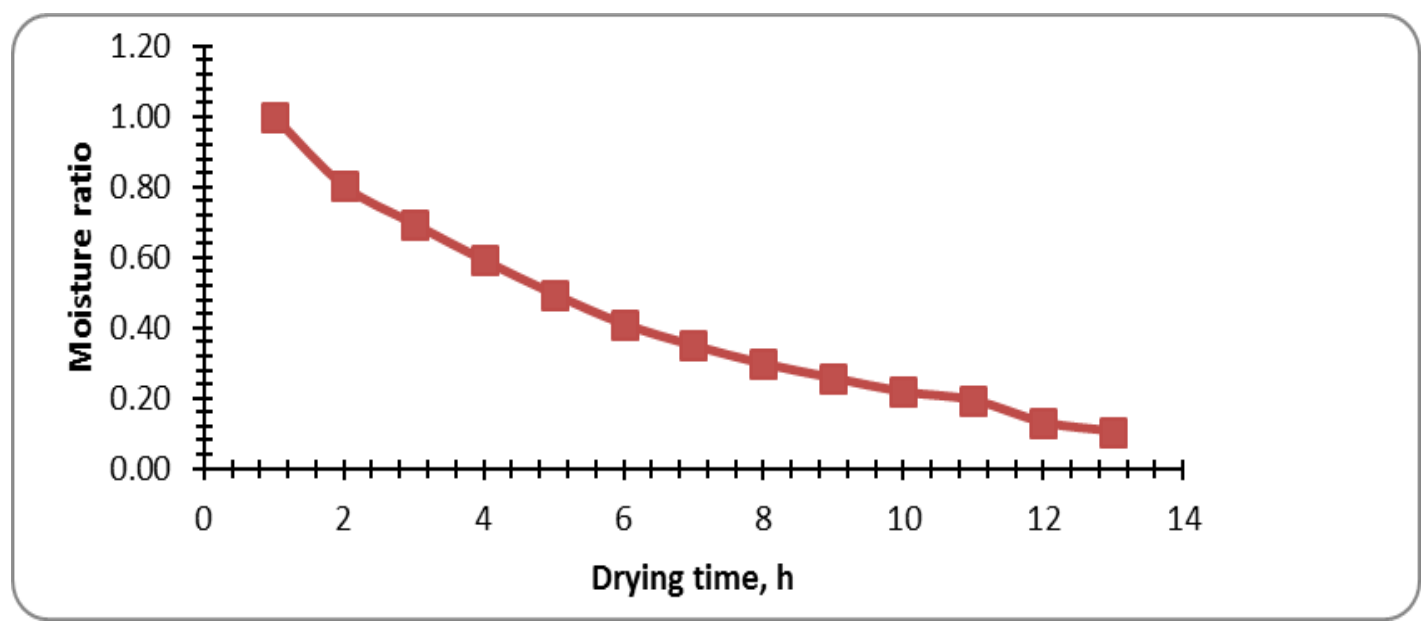


Fig.1c Variations of moisture ratio with the drying time

Fig.2 Relation of observed moisture ratio (MR) with drying time of black pepper under S-BHD and OSD methods

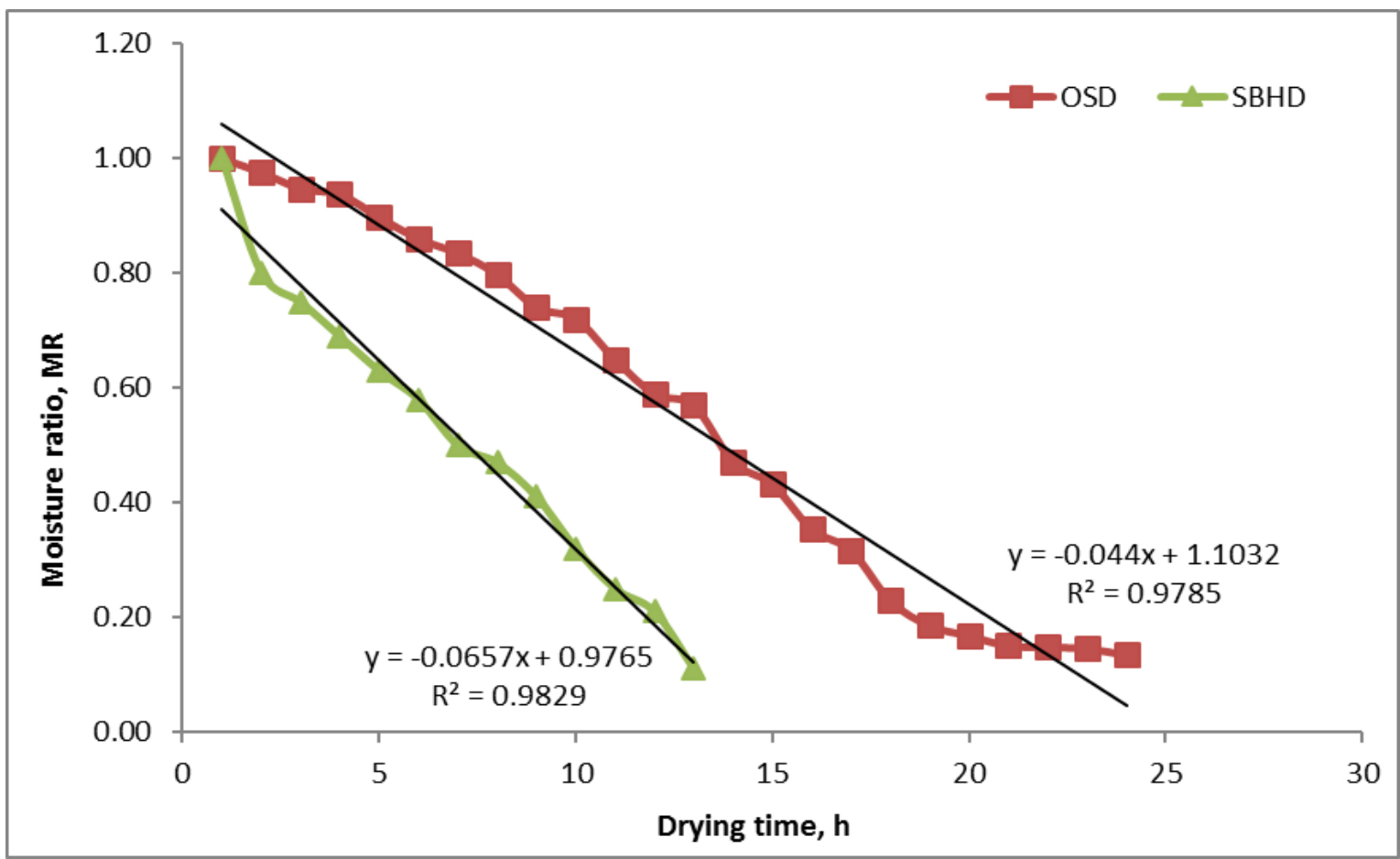

Fig.3 Experimental values and predicted values of Moisture ratio of dried black pepper determined by Midilli model in S-BHD

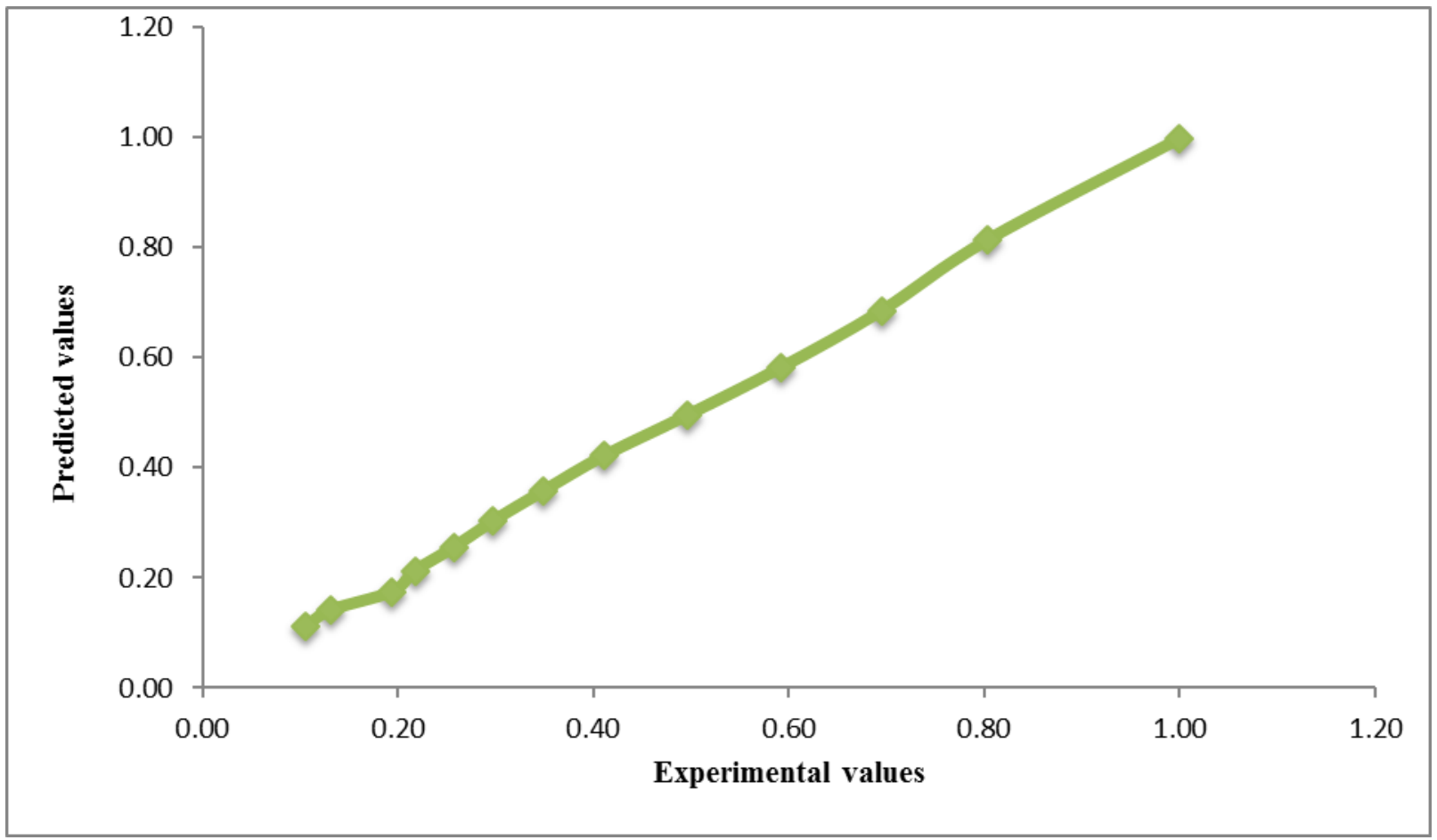


Fig.4 Experimental values and Predicted values of Moisture ratio of dried black pepper determined by Logarithmic model in OSD

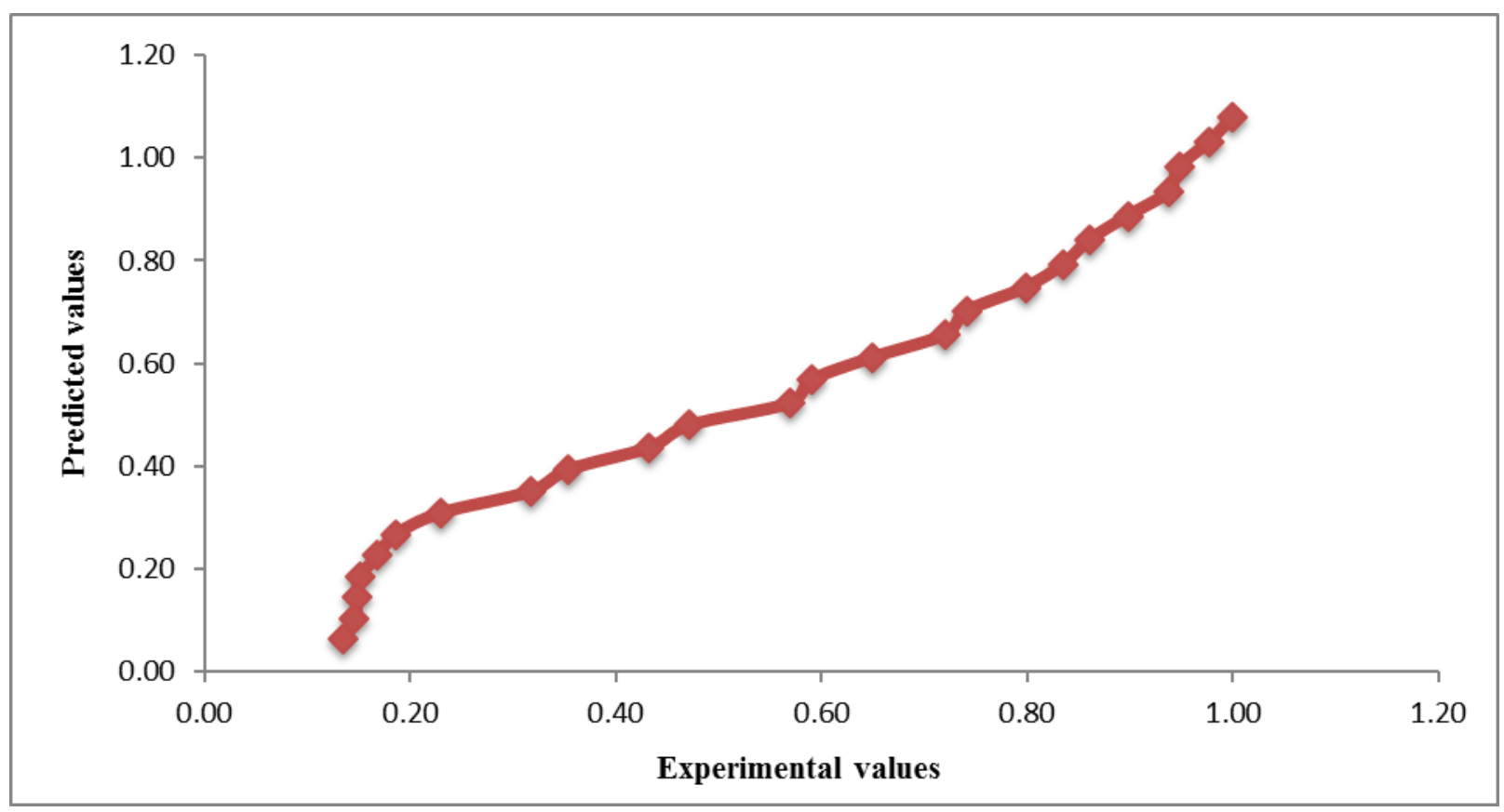

The results indicate that the initial drying efficiency of the dryer was much higher than final stage during drying. This is due to the much higher mass transfer offered by the product then it reduce the mass transfer after it is dried to a certain extent, which means that diffusion of moisture from inside the product to the surface of the product becomes difficult. The same result was observed in drying of lightly salted sardine fish by hot air drying (Bellagha et al., 2002).

The changes of moisture ratio with drying time of experiments shown in Figure 2. There is a strong linear relationship between MR with drying time for the drying of black pepper in S-BHD $\left(\mathrm{R}^{2}=0.982\right)$ and OSD $\left(\mathrm{R}^{2}=\right.$ $0.978)$ drying process. There is an inverse relationship between drying air temperature and drying time; an increasing drying temperature resulted in a decrease in the drying time, drying temperature on OSD method is lower than S-BHD. The time required to achieve $9.4 \%$ (d.b) and $12.1 \%$ (d.b) moisture content observed in the S-BHD and OSD were 12 and $84 \mathrm{~h}$, respectively. It is clear that drying rate decreases continuously with drying time.

\section{Evaluation of drying models}

The results of the statistical analysis undertaken in each model in S-BHD and OSD methods are shown in Table 2. The models were tested based on the higher $\mathrm{R}^{2}$ and low values of $\chi^{2}$ and RMSE. It was observed that the Midilli model recorded the highest $\mathrm{R}^{2}$ (0.9999) with lowest $\chi^{2}(0.00010)$ and RMSE (0.000036) in solar-biomass hybrid dryer (SBHD). The Logarithmic model recorded the highest $\mathrm{R}^{2}$ (0.9996) with lowest $\chi^{2}$ (0.0000519) and RMSE (0.0072) in open sun drying of black pepper. Hence, the Midilli and Logarithmic model gave better prediction than other models and satisfactorily described drying characteristics of black pepper in solar-biomass hybrid drying and open sun drying method, respectively. The observed and predicted values of moisture ratio of dried black pepper in S-BHD and OSD methods are 
shown in Figure 3 and 4 respectively. It is found that the differences between the experimental and predicted values are very minimal, showing that the models satisfactorily describe the characteristics of drying process.

\section{Quality analysis of dried black pepper}

\section{Biochemical analysis of final dried black pepper}

Biochemical analysis was done for black pepper dried under different methods of drying process. The samples collected from different drying methods such as solar - biomass hybrid drying and open sun drying. The biochemical analysis of finally dried black pepper reveals that, the black pepper dried under solar-biomass hybrid dryer contained the highest percentage of oleoresin, piperine and volatile oil which was $11.19 \% / \mathrm{wt}, 6.36 \%$ / wt and $5.10 \% \mathrm{v} /$ wt respectively when compared to $10.53 \% /$ wt, $5.387 \%$ / wt and $3.80 \% \mathrm{v} / \mathrm{wt}$ respectively in conventional method. Earlier, Pruthi (1993) mentioned that the piperine content of black pepper ranged between 1.7 to $7.4 \% / \mathrm{wt}$.

\section{Microbiological analysis of final dried black pepper}

The microbial analysis of final dried black pepper, it is inferred that the solar - biomass hybrid dryer is less infected by yeast and mould which is $260 \mathrm{EST}$ CFU/g when compared to conventional method which have $82,000 \mathrm{CFU} / \mathrm{g}$. This may due to drying of product in open atmosphere and non-uniform maintenance of temperature under conventional method throughout the drying process.

Drying behavior of black pepper were described by eleven different thin-layer drying models and were compared according to their root mean square error (RMSE), chisquare $\left(\chi^{2}\right)$ and coefficient of determination $\left(\mathrm{R}^{2}\right)$ values. The result of thin-layer drying of black pepper, all models showed a good correlation; however, Midilli and Logarithmic drying models were the best fitted and could be used to precisely predict the moisture content of dried black pepper in S-BHD and OSD, respectively. The average drying efficiency of the solar- biomass hybrid dryer is estimated to be about $33.9 \%$ during black pepper drying. Biochemical and Microbial analysis showed that the dried product in SBHD was in prime acceptable form for 6 months of storage at ambient temperature. Therefore, the results of the study suggest that the current design of solar-biomass hybrid dryer could now be used in helping the farmer to produce better quality of dried black pepper products.

\section{Acknowledgement}

The author would like to acknowledge Tamil Nadu Agricultural University for providing necessary facilities and sufficient funds for carrying out the project successfully.

\section{References}

Akpinar, E.K., Bicer, Y., and Midilli, A. 2003. Modeling and experimental study on drying of apple slices in a convective cyclone dryer. Journal of Food Process Engineering. 26 (6), 515-541.

ASTA, 1997. Official analytical methods of the American Spice Trade Association, 4 th Edition.

Bellagha, S., Amami, E., Farhat, A., Kechaou, N. 2002. Drying kinetics and characteristic drying curve of lightly salted sardine (Sardinella aurita). Drying Technology. 20 (7), 1527-1538.

Cassini, A.S., Marczak, L.D.F., and Norena, C.P.Z. 2007. Drying characteristics of textured soya protein: A comparison 
between three different products. Drying Technology. 25, 2047-2054.

Henderson, S.M. Progress in developing the thin layer drying equation. Transactions of the ASAE 1974, 17, 1167-1172.

Ilhan, C., Aktas, M., and Hikmet, D. 2007. Mathematical modeling of drying characteristics of tropical fruits. Applied Thermal Engineering. 27, 1931-1936.

Jain, D., and Pathare, P.B. 2007. Study of drying kinetics of open sun drying of fish. Journal of Food Engineering. 78 (4), 1315-1319.

Karathanos, V.T., and Vasilios, G.B. 1999. Application of a thin-layer equation to drying data of fresh and semi-dried fruits. Journal of Agricultural Engineering Research. 74 (3), 355-361.

Midilli, A., and Kucuk, H. 2003. Mathematical modeling of thin layer drying of Pistachio by using solar energy. Energy Conversion and Management. 44 (7), 1111-1122.

Pruthi, J.S. 1993. Major Spices of India: Crop Management and Post-Harvest Technology. pp. 80-147.

Sankat, C.K., and Mujaffar, S. 2004. Sun and solar cabinet drying of salted shark fillets. Proceedings of the 14th
International Drying Symposium, Brazil. 1584-1591.

Sharaf, E.Y.I., Blaisdell, J.L., and Hamdy, M.Y. 1980. A model for ear corn drying. Transactions of the ASAE. 5, 1261-1265.

Togrul, I.T., and Dursun, P. 2002. Mathematical modeling of solar drying of apricots in thin layers. Journal of Food Engineering. 55, 209-216.

Verma, L.R., Bucklin, R.A., Endan, J.B., and Wratten, F.T. 1985. Effect of drying air parameters on rice drying models. Transactions of the ASAE. 28, 296301.

Waewsak, J., Chindaruksa, S., and Punlek, C. 2006. A mathematical modeling study of hot air drying for some agricultural products. Thammasat International Journal of Science and Technology. 11 (1), 14-20.

Yaldiz, O., Ertekin, C., Ibrahim, U.H. 2001. Mathematical modeling of thin layer solar drying of sultana grapes. Energy. 26, 457-465.

Zhang, Q., and Litchfield, J.B. 1991. Optimization of intermittent corn drying in a laboratory scale thin layer dryer. Drying Technology. 9, 383-395.

\section{How to cite this article:}

Shreelavaniya, R., R. Pangayarselvi and Kamaraj, S. 2017. Mathematical Modeling of Drying Characteristics of Black Pepper (Piper nigrum) in Indirect Type Solar-Biomass Hybrid Dryer. Int.J.Curr.Microbiol.App.Sci. 6(11): 2634-2644. doi: https://doi.org/10.20546/ijcmas.2017.611.309 